\title{
Green Synthesis of Silver Nanoparticles From Solenostemon Monostachyus Leaf Extract and In Vitro Antibacterial and Antifungal Evaluation
}

\author{
Elisha Karu, Buhari Magaji, Zaccheus Shehu and Hadiza Abdulsalam
}

\section{ABSTRACT}

A rapid green synthesis of silver nanoparticles (AgNPs) using plant extract Solenostemon monostachyus (S. monostachyus) (Monkey's potato) with silver nitrate is reported here. The formation of AgNPs was confirmed by a colour change in the plant extract from pale yellow to reddish brown and was further characterized by ultraviolet-visible (UV-Vis) spectrophotometric, FT-IR, SEM, EDX and XRD analysis. $\mathrm{Ag}^{+}$ions were reduced by the phytochemicals present in the extract. A characteristic single broad peak was observed at $450 \mathrm{~nm}$ and has been attributed to the excitation of surface plasmon resonance phenomenon. The efficient capping and stabilization properties of the NPs were revealed by the FT-IR analysis. SEM and XRD results showed the formation of spherical shaped AgNPs with the average particle size of less than $100 \mathrm{~nm}$ and EDX confirmed the presence of silver in the prepared AgNPs. The antimicrobial properties of the biosynthesized AgNPs was evaluated against some selected bacterial and fungal species. The prepared AgNPs had notable antimicrobial activity against the selected bacterial and fungal species. Thus, the biosynthesized AgNPs could be a good lead for antimicrobial agent.

Keywords: Antimicrobial activity, Green synthesis, Silver nanoparticles, Solenostemo monastachyus.

\section{INTRODUCTION}

Nanotechnology is a fast-growing approach in the modern era. It has become one of the most active areas of research across the globe in an effort to explore the potential of synthesizing nanoparticles using different plants [1]. Nanoparticles display characteristic properties in their distribution, size and morphology. Metals used to synthesize nanoparticles are numerous some of which are copper, silver, gold, iron oxide, platinum, silica and nickel [2]. Due to their unique properties and applications, metal nanoparticles have become quite popular over the years [3] as they are used in the electronic, pharmaceutical industry etc. Silver is the most commonly used metal for synthesizing nanoparticles. It is nontoxic to humans, active at low concentrations, and exhibits various applications in the following fields: antimicrobials and therapeutics, high sensitivity bimolecular diagnostics and detection as well as catalysis and micro-electronics [4], [5]. Due to the high antimicrobial properties of AgNPs they are used in numerous household products, the medical industry and in cosmetic and pharmaceutical products. Various methods basis [2], [4].
Published Online: August 7, 2020

ISSN: $2684-4478$

DOI: 10.24018 /ejchem.2020.1.4.11

Elisha Karu*

Department of Chemistry,

Gombe State University, Nigeria.

(e-mail: elishakaru@ ${ }^{\circledR}$ ahoo.com)

Buhari Magaji*

Department of Chemistry,

Gombe State University, Nigeria.

(e-mail: magaji.buharii@gmail.com)

Zaccheus Shehu

Department of Chemistry,

Gombe State University, Nigeria.

(e-mail: zaccheusshehu@ ${ }^{\circledR}$ gmail.com)

Hadiza Abdulsalam

Department of Chemistry,

Gombe State University, Nigeria.

(e-mail: habdulsalam034@gmail.com)

*Corresponding Author

have appeared in literature for the synthesis of nanoparticles and though chemical methods are the most popular but they are often too expensive and can be toxic [2]. Green synthesis has become a more widely used approach as it is cost effective, ecofriendly and has low toxicity. Biological methods include the use of enzymes, plant extracts and microorganisms [6]. Biosynthesis using plants is the best method because it is a safer option and plants are more easily available and widely distributed [7]. Plants have been used for centuries because of their medicinal properties. Currently, the biosynthesis of AgNPs with plant extracts is being exploited because it is more economical, minimizes processing time and can be done on a small to large scale

Solenostemon monostachyus ( $S$. monostachyus), is an herb widely spread in the African continent, Asia and Australia. It occurs as an annual weed in an anthropogenic habitats and rocky savannahs. Reports [8]-[10] have shown that the various part of the plant possess a wide range of pharmacological activities including antimicrobial, anticancer, antifertility, antifungal, anti-inflammatory, antimalarial and antioxidant. In this study we report the synthesis of AgNPs with S. monostachyus leaves extract and 
evaluation of its antimicrobial activity.

\section{MAterials AND MethodS}

\section{A. Plant material and preparation of the extract}

The plant (Solenostemo monastachyus) leaves were collected from Gombe State University campus using polyethene bags. The leaves were shade-dried for two weeks and pulverized using a pestle and mortar, and then sieved to fine particles.

Aqueous extract of leaves was prepared using the fine particles $(10 \mathrm{~g})$ which was stirred in deionized water $(50 \mathrm{ml})$ followed by heating at $60{ }^{\circ} \mathrm{C}$ for one hour. The solution was then filtered with Whatman No. 1 filter paper. The filtrate was stored in a refrigerator.

\section{B. Biosynthesis and characterization}

$0.001 \mathrm{M}$ silver nitrate solution was prepared as follows: one molar silver nitrate stock solution was prepared by dissolving $\mathrm{AgNO}_{3}(0.17 \mathrm{~g})$ (BDH Chemicals Ltd) in deionized water $(100 \mathrm{ml})$. A $1 \mathrm{mM}$ solution was prepared by diluting $1 \mathrm{M}$ solution $(10 \mathrm{ml})$ in distilled water $(90 \mathrm{ml})$. This solution was stored in a dark bottle for further use at room temperature.

AgNPs were biosynthesized by mixing $20 \mathrm{~mL}$ filtrate and $1 \mathrm{mM} \mathrm{AgNO}$, and the total volume was $100 \mathrm{~mL}$. It was heated at $60^{\circ} \mathrm{C}$ until the solution colour changed (this indicated the formation of the AgNPs). UV-vis spectroscopy (PerkinElmer UV-Visible spectrophotometer model 725), Infrared spectra (Perkin Elmer spectrum 10.03.09 FTIR spectrometer), SEM, EDX and XRD were applied to characterize the synthesized nanoparticles.

\section{Antimicrobial assay}

Preliminary in vitro antibacterial screening of the biosynthesized AgNPs was carried out against one grampositive bacterium (Staphylococcus aureus) and three gramnegative bacteria (Klebsiella pneumonia and Escherichia coli and Salmonella typhimurium). The antifungal screening was carried out against two fungi namely Candida albican and Aspergellus niger. The microbial cultures were procured from the Microbiology Laboratory of the Federal Teaching Hospital, Gombe. The bacteria were sub cultured on nutrient agar media and incubated at $37^{\circ} \mathrm{C}$ for 24 hours while, the fungi were sub cultured on potato dextrose agar at $37^{\circ} \mathrm{C}$ for 72 hours in order to obtain pure and fresh isolates. Three concentrations $(50,100$ and $150 \mathrm{mg} / \mathrm{mL}$ ) of both the particle were made using DMSO. Ditch Well diffusion method was used to assay the antibacterial and antifungal activities.

The antibacterial effect of the AgNPs was performed using the procedure described by [11]. A sterile MuellerHinton agar (MHA) plates were prepared and poured in to the petri dishes and allowed to solidify. Wells were made in each plate using a sterile cork-borer $(6 \mathrm{~mm})$, after which the concentration of AgNPs was dispensed into the bored holes. The plates were left to stand to allow diffusion of the particle after which it was incubated at $37^{\circ} \mathrm{C}$ for 24 hours. The diameter of zone of inhibition (ZI) was measured and recorded using a meter rule (in $\mathrm{mm}$ ). Based on the preliminary screening results, the minimum inhibition concentrations (MICs) were determined. The aqueous dispersions of AgNPs were serially diluted 2-fold with water ranging from $0.1-500 \mu \mathrm{gmL}^{-1}$ and $5 \mu \mathrm{l}$ of each concentration was spotted on the lawn inoculated MHA plates and incubated at $37{ }^{\circ} \mathrm{C}$ for 24 hours. The crude extracts and $\mathrm{AgNO}_{3}$ solution served as controls.

The antifungal activity of the AgNPs was tested by well diffusion method $[12,13]$. The activity was tested for in vitro growth inhibitory activity against two fungi $C$. albican and A. niger cultured on potato dextrose agar. Three different solutions of 50,100 , and $150 \mathrm{mg} / \mathrm{mL}$ of the AgNPs were prepared in DMSO. The crude extracts and $\mathrm{AgNO}_{3}$ solution were used as a control. Solution of the AgNPs was poured on to the culture agar medium and was incubated for a period of 72 hours at $37^{\circ} \mathrm{C}$. After the incubation period the plates were observed for ZI (in mm) [12,13]. These activities were performed three times and reported as mean of all the three readings.

\section{Results AND Discussion}

\section{A. Biosynthesis of AgNPs}

Previous studies [2], [7], [14], [15] have shown that the first step indicating the biosynthesis of the $\mathrm{Ag}$ nanoparticles is the bio-reduction of $\mathrm{AgNO}_{3}\left(\mathrm{Ag}^{+}\right)$to elemental silver $\left(\mathrm{Ag}^{\circ}\right)$ and that it is accompanied by a colour change from pale yellow to reddish brown. This visual colour change was indeed observed in this study and also by some other previous studies [15]-[18].

\section{B. UV - visible spectra analysis}

Singh et al., [19] reported that the absorption spectra of AgNPs have unique absorption maximum in the range 440$460 \mathrm{~nm}$. The UV-vis spectrum from this work showed a strong absorption peak at $450 \mathrm{~nm}$. This absorption band has been attributed [20] to surface plasmon resonance (SPR) in AgNPs

The UV-Vis spectra recorded implied that the bioreduction was achieved at $60{ }^{\circ} \mathrm{C}$. This was denoted by broadening of the peaks that was indicative of the formation of large polydispersed nanoparticles due to slow reduction rates [3]. However, there was no obvious characteristic absorbance peak of AgNPs for $\mathrm{AgNO}_{3}$ or leaf filtrate alone. It has been proven that the two portions were both needed for the biosynthesis of AgNPs, and the biological method also avoided the disadvantages of chemical and physical approaches such as the usage of additional chemical reagents, high energy consumption, and high cost [21]. 


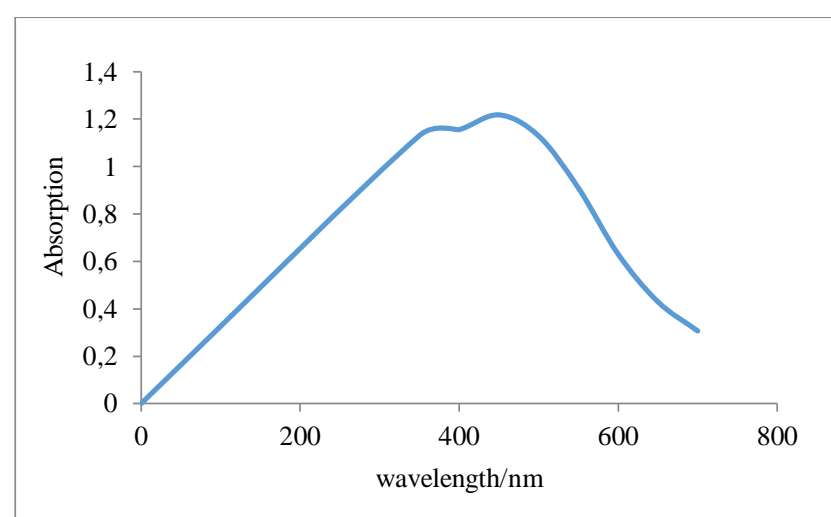

Fig. 1. UV-spectrum of AgNPs supernatant acquired on a PerkinElmer 725 UV-visible spectrophotometer in $1 \mathrm{~cm}$ path length quartz cuvette against deionized water in the reference beam.

\section{FTIR spectra analysis}

FTIR analysis was carried out to characterize the potential biomolecules responsible for the reduction of $\mathrm{Ag}^{+}$ions and the stabilization of the bio-reduced silver nanoparticles to prevent nanoparticles clustering and capping in the aqueous medium as was done by Basavaraja et al., [22]. The absorption peak at $1640-1550 \mathrm{~cm}^{-1}$ is close to that reported for proteins, suggesting that proteins are interacting with biosynthesized AgNPs. Absorption peaks occurring between 3650-3200 $\mathrm{cm}^{-1}$ denote alcohols (O-H bands) possibly arising from proteins and carbohydrates present in the sample which is in agreement with the value reported in the literature [19,23-24]. The FTIR spectra of the extract and the bio-reduced silver nanoparticles recorded from 500 to 4000 $\mathrm{cm}^{-1}$ are presented in Figures 2(a) and 2(b). A broad peak at around $3500 \mathrm{~cm}^{-1}$ and other intensive peaks at 1601, 1384 and $1031 . \mathrm{cm}^{-1}$ were corresponding to various functional groups and demonstrated the existence of protein stabilizing molecules.

The broad peak around $3500 \mathrm{~cm}^{-1}$ corresponding to $\mathrm{O}-\mathrm{H}$ stretching [25]. The strong peak at $1601 \mathrm{~cm}^{-1}$ is associated with $-\mathrm{C}=\mathrm{O}$ [26]. The very sharp peak at $1384 \mathrm{~cm}^{-1}$ can be assigned to be associated with benzene ring stretching of $\mathrm{C}=\mathrm{C}$ and $\mathrm{C}-\mathrm{C}$ bonds [27-28]. The peak at $1031 \mathrm{~cm}^{-1}$ can be attributed to $\mathrm{C}-\mathrm{O}$. The reduction and stability of silver ions $\mathrm{Ag}^{+}$into Nano size silver particles $\mathrm{Ag}^{\circ}$ could be due to the presence of phytochemicals such as flavonoids triterpenoids, phenolic, carboxylic and amide groups in the leaves extract of $S$. monostachyus. These phytochemicals have powerful ability to bind silver nanoparticles, acting as capping agents and hence provide the stability to them which is consistent with the earlier reports of plant extracts mediated synthesis of AgNPs [19,29]. FTIR analysis revealed that polyphenols could function as bio reducing agents, while proteins could play a dual role as bio-reducing and stabilizing agents.

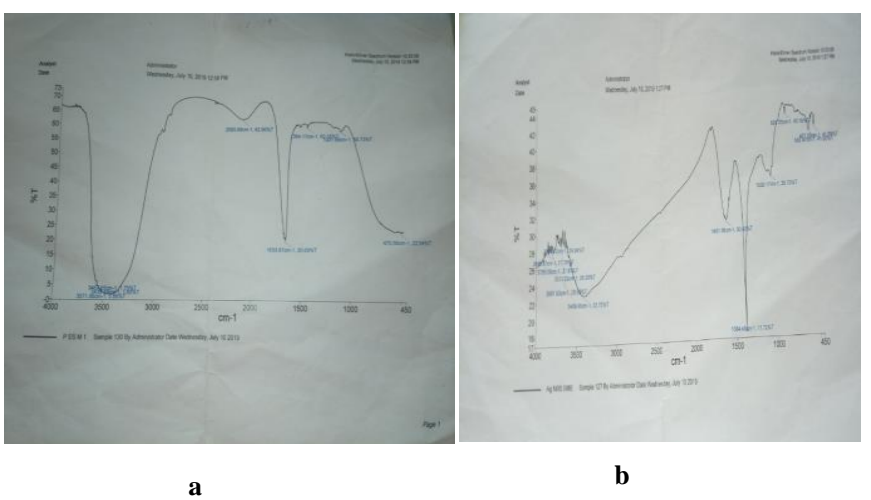

Fig. 2. FTIR spectra of (a) plant extract (b) AgNPs acquired on a PerkinElmer spectrum 10.03.09.

\section{Scanned Electron Microscopy (SEM) and X-ray Diffraction studies (XRD)}

The morphology of the biosynthesized AgNPs were studied using scanned electron microscopy. Fine nanoparticles of silver which are nearly spherical having smooth surface and well dispersed with close compact arrangement were observed in the SEM micrographs as shown in Figure 3(a). The uniform distribution of AgNPs was found, and it may be due to the phenomenon of stabilization of synthesized AgNPs by the phytochemicals present in the S. monostachyus leaves extract. The EDX spectrum revealed the elemental composition of biosynthesized AgNPs as presented in Figure 3(b). A strong peak for the silver signal at $82.32 \%$ (weight percentage) was observed in the EDX spectrum. The EDX profile confirmed that pure AgNPs were synthesized by $S$. monostachyus leaves extract and the presence of extra peaks may be due to the chemical or biological impurities present in the plant extract.

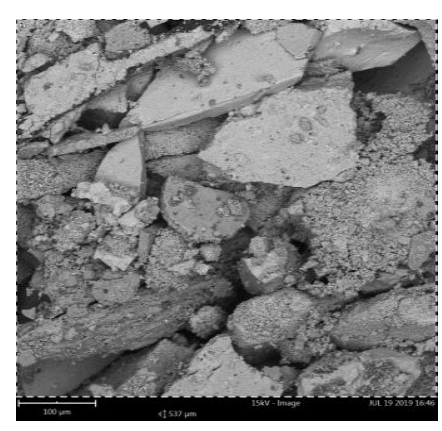

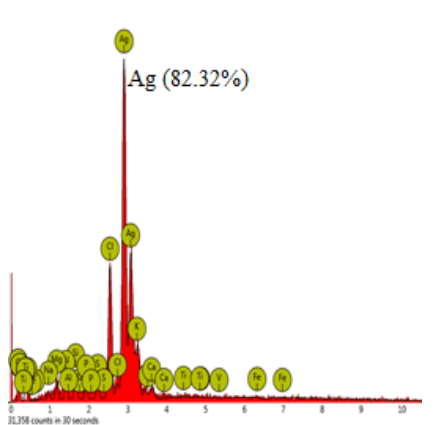

b
Fig. 3. (a) SEM micrographs (b) EDX spectrum of

AgNPs synthesized with $S$. monostachyus extract. Figure 4 shows the XRD analysis of the AgNPs. The diffractogram illustrates diffraction peaks at $2 \theta=28.2^{\circ}, 32.6^{\circ}, 34.0^{\circ}$, $38.5^{\circ}, 44.7^{\circ}$ and $46.5^{\circ}$. The well-defined peaks indicate high crystallinity of the AgNPs, corresponding to a unitary cell for Nano crystals with crystal size of $32.17 \mathrm{~nm}$. The UV-vis spectroscopy, FTIR, SEM, EDX and XRD results confirm the formation of AgNPs when using the S. monastachyus leaves extract as a reducing and stabilizing agent. 


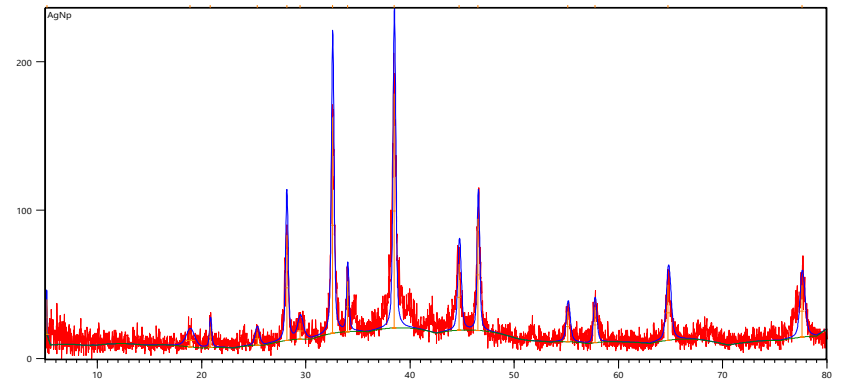

Fig. 4. X-ray diffraction of AgNPs synthesized with $S$. monostachyus leaves extract.

The results of the antimicrobial assay of the silver nanoparticles synthesized by $S$. monostachyus are given in Table 1. It is clear from the results that the bactericidal action of AgNPs against gram-negative bacterium E. coli $(13.0 \mathrm{~mm})$ was found to be better in comparison to grampositive bacterium $S$. aureus $(11.5 \mathrm{~mm})$. The activity increased with increase in concentration of the synthesized AgNPs. However, the biosynthesized AgNPs showed a weak activity against the remaining tested gram-negative bacteria $S$. typhimurium $(6.0 \mathrm{~mm})$ and $K$. pneumonia $(6.0$ $\mathrm{mm})$. More so, AgNPs was also effective against the tested fungal strains (Table 1). The bactericidal mechanism of AgNPs was attributed by either attaching to cell membrane surface disturbing the permeability or by penetrating inside the cytoplasm to inhibit the metabolic activities leading to cell lysis as reported in literature [30-31].

Our results provide a valuable reference for the future treatment of bacterial and fungal diseases. The ability to biosynthesize AgNPs using S. monostachyus is highly promising as a simple and reproducible process of sustainable green synthesis. Nevertheless, additional in vivo studies should be undertaken to better understand the efficacy of the particles before developing them for clinical applications.

TABLE 1: Antimicrobial activity AgNPs synthesized with $S$ monostachyus leaves extract.

\begin{tabular}{|c|c|c|c|c|}
\hline \multirow{2}{*}{$\begin{array}{l}\text { Tested } \\
\text { organism }\end{array}$} & \multicolumn{4}{|c|}{ Zone of Inhibition (mm) } \\
\hline & $100 \mu \mathrm{g} / \mathrm{L}$ & $200 \mu \mathrm{g} / \mathrm{L}$ & $300 \mu \mathrm{g} / \mathrm{L}$ & $400 \mu \mathrm{g} / \mathrm{L}$ \\
\hline Gram-positive & & & & \\
\hline $\begin{array}{l}\text { S. aureus } \\
\text { Gram-negative }\end{array}$ & 6.00 & 6.00 & 6.00 & 11.50 \\
\hline S. typhimurium & 6.00 & 6.00 & 6.00 & 6.00 \\
\hline E. coli & 6.00 & 6.50 & 8.00 & 13.00 \\
\hline K. pneumonia & 6.00 & 6.00 & 6.00 & 6.00 \\
\hline Fungi & & & & \\
\hline A. niger & 14.00 & 18.00 & 20.50 & 22.50 \\
\hline C. albican & 6.00 & 6.00 & 6.00 & 6.00 \\
\hline
\end{tabular}

Key: Inhibitory action < 9: weak, 9-16: moderate, >16: significant.

\section{CONCLUSION}

Green synthesis of AgNPs using S. monostachyus leaves extract was investigated in this study. The presence of phytochemicals in the $S$. monostachyus leaves was examined by FTIR analysis. Furthermore, phytochemicals present in the leaves extract of $S$. monostachyus could assist the formation of AgNPs and the corresponding compounds might work as the reducing and capping agent. More so, the biosynthesized AgNPs were found to be spherical with the size lesser than $100 \mathrm{~nm}$ which was confirmed by SEM and XRD analyses respectively. The presence of $\mathrm{Ag}$ in the biosynthesized AgNPs was confirmed by EDX analysis. The synthesized AgNPs were found to be a potential antimicrobial agent thus, demonstrating that AgNPs could be used as an alternative for treating bacterial and fungal infections. This work has further affirmed that the biosynthesis of nanoparticles by $S$. monostachyus plant extract is feasible, safe, cheap, less time consuming and no hazardous chemicals involved.

\section{REFERENCES}

[1] Govindappa, M., Farheen, H, Chandrappa, C.P. Channabasava, R., Rai, R.V. and Raghavendra, V.B. (2016) Mycosynthesis of silver nanoparticles using extract of endophytic fungi, Penicillium species of Glycosmis mauritiana, and its antioxidant, antimicrobial, anti-inflammatory and tyrokinase inhibitory activity. Adv. Nat. Sci.: Nanosci. Nanotechnol. 7: 035014.

[2] Ittiyavirah, S.P. and Paul, A.S. (2016). Gastroprotective effect of plumbagin and ethanolic extract of plumbaginals in experimentally induced ulcer. J. HerbMed. Pharmacol. 5: 92-98.

[3] Kumar, T.S.J., Balavigneswaran, C.K., Packiaraj, R.M., Veeraraj, A., Prakash, S., Hassen, Y.N. and Srinivasakumar, K.P. (2013). Green Synthesis of Silver Nanoparticles by Plumbago indica and Its Antitumor Activity Against Dalton's Lymphoma Ascites Model. Bio. Nano. Science, 3: 394-402.

[4] Subedi, D.P., Madhup, D.K., Sharma, A., Joshi, U.M., Huczko, A. (2012). Study of the wettability of $\mathrm{ZnO}$ nanofilms. Int. Nano Lett. 2(1): 1-6.

[5] Erjaee, H., Rajaian, H. and Nazifi, S. (2017). Synthesis and characterization of novel silver nanoparticles using Chamaemelum nobile extract for antibacterial application. Adv. Nat. Sci.: Nanosci. Nanotechnol. 8(2): 025004.

[6] Jain, D., Daima, H.K., Kachhwaha, S. and Kothari, S.L. (2009) Synthesis of plant mediated silver nanoparticles using papaya fruit extract and evaluation of their antimicrobial activities. Dig. J. Nanomater. Biostruct. 4(3): 557-563.

[7] Banerjee, P., Satapathy, M., Mukhopahayay, A. and Das, P. (2014). Leaf extract mediated green synthesis of silver nanoparticles from widely available Indian plants: synthesis, characterization, antimicrobial property and toxicity analysis. Bioresour. Bioprocess 1(3): $1-10$

[8] Ajibesin, K.K, Ekpo, B.A, Bala, D.N, Essein, E.E. and Adesanya S.A. (2008). Ethno botanical Survey of Akwa Ibom State of Nigeria J. Ethnopharmacol. 115: 387-408.

[9] Koffi, N., Marie-Solange, T., Emma, A.A. and Noel, Z.G. (2009) Ethno botanical Study of plants used to treat arterial hypertension in traditional medicine, by Abbey and Krobou Population of Agboville. Eur. J. Sci. Res., 35: 85-98

[10] Adebayo, J.O. and Krettli, A.U. (2011). Potential Antimalarial from Nigerian Plants: A Review J. Ethnopharmacol. 133: 289-302.

[11] Hossein, J., Jelas, H., Mohd, H.S.I, Roshana-Rafiee, M., Afsah-Hejri, L., Abdollahi, Y., Rezayi, M. and Vafaei, N. (2013). Well Diffusion Method for Evaluation of Antibacteria.Activity of Copper Phenyl Fatty Hydroxamate Synthesized from Canola \& PalmKernel Oils. Dig. J. Nanomater. \& Biostruc., 8 (3) 1263-1270.

[12] Gopinath, M., Bharathiraja, B., Iyyappan, J., Gnanasekaran, R., Yuvaraj, D. and Dhithy, V. (2020). Extracellular Green Synthesis of Silver Nanoparticles Using Extract of Mimosa pudica Leaves and Assessment of Antibacterial and Antifungal Activity. Proc. Natl. Acad. Sci., India, Sect. B Biol. Sci. https://doi.org/10.1007/s40011020-01175-1.

[13] Al-Zubaidi, S., Al-Ayafi, A. and Abdelkader, H. (2019). Biosynthesis, Characterization and Antifungal Activity of Silver Nanoparticles by Aspergillus Niger Isolate. J. Nanotechnol. Res. 2019; 1 (1): 023-036.

[14] Borase, H.P., Salunke, B.K. and Salunkheetal, R.B. (2014). Plantextract: a promising biomatrix for ecofriendly, controlled 
synthesis of silver nanoparticles. Applied Biochem. and Biotechnol. 173(1): 1-29.

[15] Rao, B. and Tang, R.C. (2017). Green synthesis of silver nanoparticles with antibacterial activities using aqueous Eriobotrya japonica leaf extract. Adv. Nat. Sci.: Nanosci. Nanotechnol. 8(1): 015014

[16] Chandran, S.P., Chaudhary, M., Pasricha, R., Ahmad, A. and Sastry, M. (2006). Synthesis of Gold Nanotriangles and Silver Nanoparticles Using Aloe vera Plant Extract. Biotechnol. Program. 22: 577-580.

[17] Ebrahiminezhad, A., Bagheri, M., Taghizadeh, S.M., Berenjian, A. and Ghasemi, Y. (2016). Biomimetic synthesis of silver nanoparticles using microalgal secretory carbohydrates as a novel anticancer and antimicrobial. Adv. Nat. Sci.: Nanosci. Nanotechnol. 7(1): 015018.

[18] Mittal, J., Jain, R. and Sharma, M.M. (2017). Phytofabrication of silver nanoparticles using aqueous leaf extract of Xanthium strumerium L. and their bactericidal efficacy. Adv. Nat. Sci.: Nanosci. Nanotechnol. 8(2): 025011.

[19] Singh, K., Naidoo, Y., Mocktar, C. and Baijnath, H. (2018). Biosynthesis of silver nanoparticles using Plumbago auriculata lea and calyx extracts and evaluation of their antimicrobial activities. Adv. Nat. Sci.: Nanosci. Nanotechnol. 9: 1-9.

[20] Bar, H., Bhui, D.K., Sahoo, G.P., Sarkar, P., Pyne, S., and Misra, A. (2009). Green synthesis of silver nanoparticles using seed extract of Jatropha curcas. Colloids and Surfaces A: Physicochem. Enginee. Aspects, 348(1-3): 212-216.

[21] Dubey, S.P., Lahtinen, M. and Sillanpaa, M. (2010). Trans fruitmediated greener synthesis of silver and gold nanoparticles. Process Biochem., 45(7): 1065-1071.

[22] Basavaraja, S., Balaji, S., Lagashetty, K., et al. (2008). Extracellular biosynthesis of silver nanoparticles using the fungus Fusarium semitectum. Mater Res Bull 43: 1164-1170.

[23] Danbature, W.L., Shehu, Z., Mai, A.J., Magaji, B., Adam, M.M. and Bunu, M.A. (2020). Green synthesis, characterization and larvicidal activity of $\mathrm{Cu} / \mathrm{Ni}$ bimetallic nanoparticles using fruit extract of Palmyra palm. Int. Journal of Chem. Mat. Research, 8(1): 20-25.

[24] Shehu, Z., Danbature, W.L., Magaji, B., Adam, M.M., Bunu, M.A. Mai, A.J. and Mela, Y. (2020). Green synthesis and nanotoxicity assay of copper-cobalt bimetallic nanoparticles as a novel nanolarvicide for mosquito larvae management. Int. Journal of Biotech., 9 (2): 99-104.

[25] Bozanic, D.K., Trandafilovic, L.V., Luyt, A.S., et al. (2010). Green synthesis and optical properties of silver-chitosan complexes and nanocomposites. React Function Polym. 70: 869-873.

[26] Sivaraman, S.K., Elango, I., Kumar, S., et al. (2009). A green protocol for room temperature synthesis of silver nanoparticles in seconds. Current Sciences 97: 1055.

[27] Khandelwal, N., Abhijeet, S., Devendra, J., et al. (2010). Green synthesis of silver nanoparticles using Argimone mexicana leaf extract and evaluation of their antimicrobial activities. Dig. J. Nanomat. Biostruct. 5: 483-489.

[28] Gipson, K., Stevens, K., Brown, P., et al. (2015). Infrared Spectroscopic Characterization of Photoluminescent Polymer Nanocomposites. Journal of Spectroscopy: 9.

[29] Prasannaraj, G. and Venkatachalam, P. (2017). Green engineering of biomolecule-coated metallic silver nanoparticles and their potentia cytotoxic activity against cancer cell lines. Adv. Nat. Sci.: Nanosci. Nanotechnol., 8(2): 025001 (11pp).

[30] Duran, N., Marcato, P.D., Conti, R.D., Alves, O.L., Costab, F.T.M., Brocchi, M. (2010). Potential use of silver nanoparticles on pathogenic bacteria, their toxicity and possible mechanisms of action. J. Braz. Chem. Soc. 21: 949-959.

[31] Prabhu, S., Poulose, E.K. (2012). Silver nanoparticles: mechanism of antimicrobial action, synthesis, medical applications, and toxicity effects. Nano Lett. 2: 1-10.

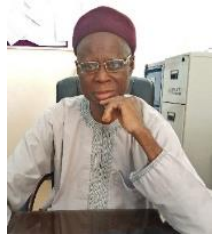

Elisha Karu, obtained his $\mathrm{PhD}$ from the University of East Anglia Norwich, UK in 1991 with area of interest in synthetic chemistry and kinetic studies of trinuclear metal carboxylates of the first row transition metals $\mathrm{Fe}, \mathrm{Cr}, \mathrm{Mn}$ in particular and their mixed metal complexes using infrared spectroscopy as a probe. He is currently also involved in green chemistry of some transition metal nanoparticles obtained from plant extracts. He is and has been a Senior Lecturer with the Department of Chemistry Gombe State University and engaged in academic supervision of Postgraduate Students and administrative duties as the Dean Faculty of Science since 2014.

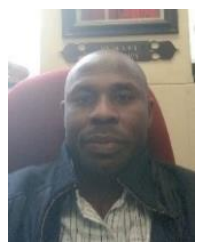

Buhari Magaji, obtained $\mathrm{PhD}$ in Chemistry for his study on the science of ultraviolet (UV) filters in 2019 from the University of KwaZulu-Natal, Durban, South Africa. He is presently a Lecturer in the Department of Chemistry, Gombe State University, with more than 8 years of teaching and research experience. He has published twenty-seven (27) research papers in national and international journals and currently guiding/supervising number of postgraduate and undergraduate students.

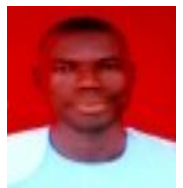

Zaccheus Shehu, Lecturer II, Chemistry department, faculty of Science, Gombe State University, Nigeria. He got his M.Sc. degree in Chemistry from University of Ilorin, Nigeria. He has published more than twenty articles in national and international journals. His main field of research is synthesis, characterization and applications of nanomaterials.

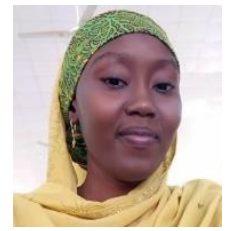

Hadiza Abdulsalam, obtained NCE certificate in 2012, from Aminu Saleh College of Education Azare. She then proceeded to the prestigious Gombe State University, where she obtained her bachelor's degree in chemistry (ed.) in 2016, and presently pursuing her master of science inorganic chemistry. 